JOURNAL OF SECURITY AND SUSTAINABILITY ISSUES

ISSN 2029-7017 print/ISSN 2029-7025 online

2021 Volume 11

https://doi.org/10.47459/jssi.2021.11.49

\title{
MANAGING THE FINANCIAL SECURITY OF ORGANIZATIONS DURING THE COVID-19 PANDEMIC - MULTIVARIATE ANALYSIS ${ }^{1}$
}

\author{
Juliusz Piwowarski ${ }^{1}$, Bartosz Kozicki ${ }^{2}$, Marcin Jurgilewicz ${ }^{3}$, Norbert Malec ${ }^{4}$ \\ ${ }^{1}$ University of Public Safety and Individual APEIRON in Krakow, Poland \\ ${ }^{2}$ Military University of Technology, Warsaw, Poland \\ ${ }^{3}$ Rzeszów University of Technology, Poland \\ ${ }^{4}$ University of Natural Sciences and Humanities in Siedlce, Poland \\ E-mails: ${ }^{1}$ rektorat@apeiron.edu.pl; ${ }^{2}$ bartosz.kozicki@wat.edu.pl; ${ }^{3}$ m.jurgilewicz@prz.edu.pl; ${ }^{4}$ norbek@poczta.fm
}

Received 18 September 2021; accepted 10 November 2021; published 30 December 2021

\begin{abstract}
The study includes an analysis of the functioning of micro, small and medium-sized enterprises during the COVID-19 pandemic from the perspective of financial security management of these entities. The article covers the identification of threats in the area of finances of the discussed enterprises that arose during the pandemic, as well as the assessment and approach to financial risk management in these entities. As a result, the key categories of threats to the financial security of enterprises, arising during the COVID-19 pandemic, were presented, as well as the assessment of the effectiveness of state services responsible for ensuring financial security. The study focuses on multidimensional data analysis in terms of their grouping and unraveling in terms of comparing the considered variables in terms of dynamics. Initial studies were performed by comparing several variables, and the data were analyzed not only during the COVID-19 pandemic, but also in the pre-pandemic period in terms of observing their fluctuations in dynamic terms, and the relationships between them were also examined.
\end{abstract}

Keywords: security; finance; COVID-19.

Reference to this paper should be made as follows: Piwowarski, J., Kozicki, B., Jurgilewicz, M. Malec, N. 2021. Managing the financial security of organizations during the Covid-19 pandemic - multivariate analysis. Journal of Security and Sustainability Issues, 11, 537-546. https://doi.org/10.47459/jssi.2021.11.49

JEL Classifications: G01

Additional disciplines: political sciences and administration, law

\section{Introduction}

The first case of COVID-19 in the world was recorded in December 2019 in Wuhan, China (Zhu, Zhang, et al., 2020), while the first case of the COVID-19 infectious disease in Poland was observed on March 4, 2020 (Ministry of Health, 2020). The World Health Organization on March 11, 2020 declared COVID-19 a pandemic (Satomi, et al., 2020). The pandemic led to: a reduction in transport, especially in the aviation sector, a crisis in medical care, including the need to establish temporary hospitals, as well as the mandatory increase in the use of various preventive measures, including those for disinfection (Matuka, 2020). This, in turn, led to a decrease in the demand for crude oil and its global price drops (Kingsly, Kouam, 2020), even to the level of around \$9 per barrel. As a result, the largest economy in the world, i.e. the United States, recorded a very strong increase in unemployment rates to the level of 14.7\% in April 2020 (Mitkow, Kozicki, 2020). The increase in unemploy-

1 The article was financed from the funds received from the grant for support under the international grant project No. GA/23/2020 implemented by the Authors. 
ment was also visible in Poland, but slowed down by measures implemented by the government in the form of financial and anti-crisis shields (Serwis Rzeczypospolitej Polskiej, 2020). The slowdown in the air transport sector, drops in oil prices, rising unemployment rates and other factors have undermined the economic security of countries around the world, including Poland.

In the scientific literature, the concept of security, undoubtedly denoting a state of non-threat, is an example of a term that, for proper use, requires clarification of what kind of freedom from danger is meant (Jurgilewicz, 2017). Therefore, in theory, the accepted divisions of security allow to distinguish between external and internal security, and within the framework of internal security, there are numerous categories of generic security. One of them is financial security, which is sometimes interchangeably referred to as economic security. Continuing that the essence of this type of security is the certainty of survival and development of the state's economic system and the maintenance of its international position (Nurzyńska, 2016, p. 22), it can be concluded that financial security is characterized by: stability (unchangeability), certainty, attitude to the challenges posed by from the external environment, connections with foreign partners or the role of the market and the state (Kurek, 2000, p. 28). Maintaining financial security is particularly important for countries around the world and requires effective fight against the encountered adversities which constitute - depending on the scale - more or less important threats to this type of security. On the other hand, one of the forms of counteracting these threats are assessments resulting from multidimensional comparative data analyzes that reflect the condition and prosperity of the state in this aspect. A multidimensional comparative analysis is identified with the ordering of a relatively homogeneous set of objects in order to make decisions (Luniewska, Tarczyński, 2006, p. 10). Therefore, volatility is one of the most important terms in modern finance, both in theoretical and practical terms in terms of maintaining financial security.

\section{Financial security of micro, small and medium-sized enterprises}

Pursuant to Art. 9 of the Act of 6 March 2018, Entrepreneurs' Law (Journal of Laws of 2021, item 162, as amended), a micro-entrepreneur is an entrepreneur who in at least one year of the last two financial years met the following conditions: more than 10 employees and achieved an annual net turnover from the sale of goods, products and services and financial operations not exceeding the PLN equivalent of EUR 2 million, or the sum of assets of its balance sheet prepared at the end of one of these years did not exceed the PLN equivalent of EUR 2 million.

The definition of a small entrepreneur boils down to specifying that it is an entrepreneur who, in at least one of the last two financial years, met the following conditions jointly: employed an average of less than 50 employees per year and achieved an annual net turnover from the sale of goods, products and services as well as from operations financial instruments not exceeding the PLN equivalent of EUR 10 million, or the total assets of its balance sheet prepared at the end of one of these years, did not exceed the PLN equivalent of EUR 10 million and which is not a microenterprise. In turn, a medium-sized entrepreneur is an entrepreneur who, in at least one of the last two financial years, met the following conditions jointly: he employed an average of less than 250 employees and achieved an annual net turnover from the sale of goods, products and services and from financial operations not exceeding the PLN equivalent of 50 million euro, or the sum of assets of its balance sheet prepared at the end of one of these years did not exceed the PLN equivalent of EUR 43 million and which is not a micro or small entrepreneur. The cited legal definition of micro, small and medium-sized enterprises, which are briefly designated as SMEs, shows the essence of this sector of the market economy, and, importantly, these entities are of key importance for economic development in Poland, because they are necessary for the sustainable functioning of the economy and contribute to acceleration economic growth.

The Encyclopedia of Management indicates that the main features of the SME sector include in particular: the ability to respond very quickly to market needs, openness to technical and organizational progress, potential ability to create new jobs, low cost of a job, ease of adaptation to place, time and resources, occurrence in all sectors of the economy. SMEs are an integral part of the region's internal forces that determine its development, they are mainly local and regional, and the local market is their primary source of supply with labor resources, 
materials, etc., as well as the main outlet for the majority of companies. In essence, the development of small and medium-sized enterprises consists in introducing positive process, product, technological and structural changes, allowing the company to adapt to the changes taking place and build a competitive advantage on the market (Zimon. Jurgilewicz, Kmiotek, 2020).

\section{A multidimensional comparative analysis of the number of private enterprises in Poland along with the activities of government administration bodies in the aspect of counteracting COVID-19}

The research began with a comparison of the difference in the number of newly established and liquidated enterprises (micro, small and medium) in Poland in 2008-2020 in thousands of (fig. 1).

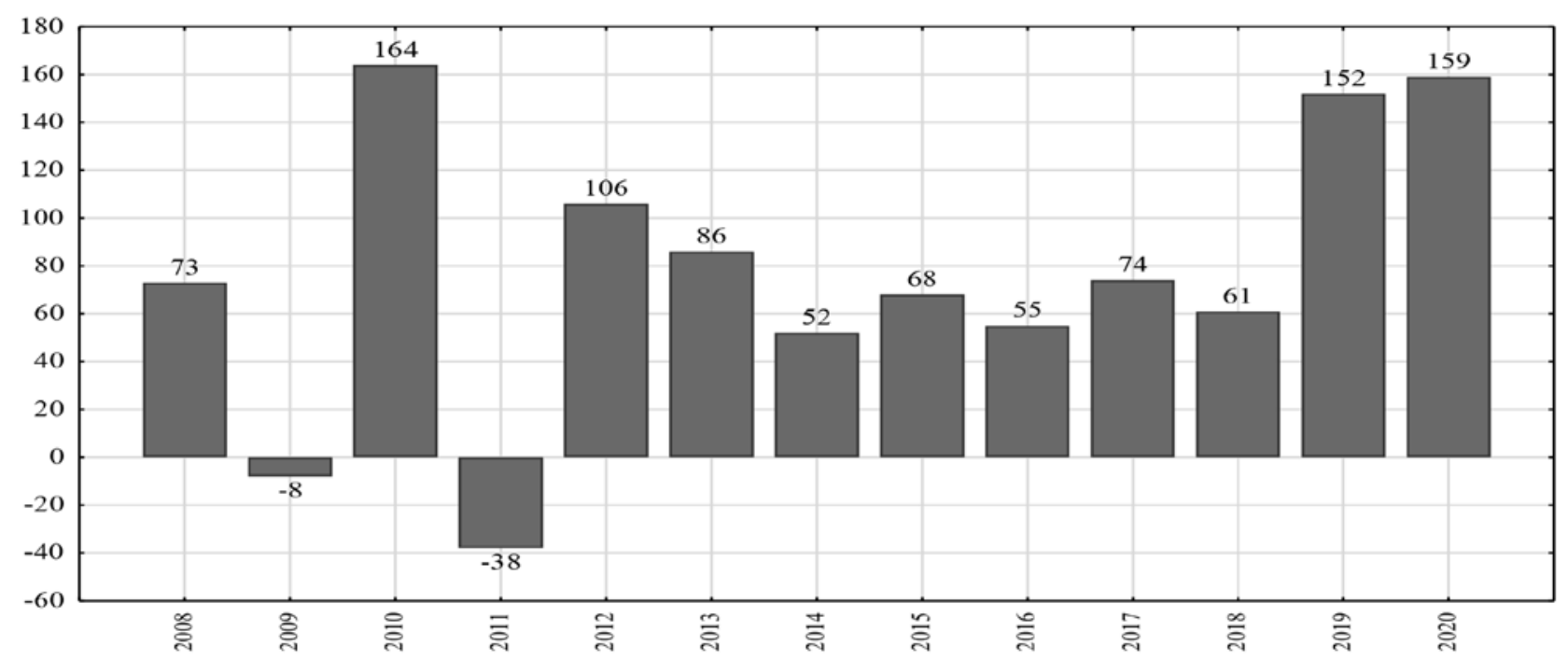

Figure 1. Bar chart of the difference in the number of newly established and liquidated enterprises in Poland in 2008-2020 in thousand.

Source: https://www.parp.gov.pl/storage/publications/pdf/PARP-26_Raport-2021-07-22_WCAG_210726.pdf

(Date of access: October 14, 2021).

The assessment of the visual observation of the data outlined in Figure 1 is the statement that during the global financial crisis (2007-2009), and in fact in its final stage, a decline in the increase in the number of enterprises in Poland in 2009 at the level of 8,000 enterprises was observed. 2010 saw a strong increase in the number of new enterprises in Poland. About 402,000 companies registered during this time and 238,000 went bankrupt, leading to an increase of about 164,000 companies. In 2011, a record number of registered failed enterprises was observed at the level of 384,000, which led to a decline in the increase in the number of enterprises in Poland at the level of 38,000 enterprises. In the years 2012-2018, a constant level of increase in the number of enterprises in Poland was visible, oscillating alternately around the arithmetic average of 72,000 enterprises per year. On the other hand, in the 2019-2020 period, a strong increase in the number of enterprises was observed. In 2019 it amounted to 152,000 , and in 2020 it increased to 159,000 . It should be emphasized that in 2019 there were 379,000 newly registered enterprises in Poland, while 152,000 were declared bankrupt. In 2020, only 329,000 newly established enterprises were registered, and bankruptcy announced the least in the entire analyzed period 2008-2020, as 170,000. The situation related to the low level of new and bankrupted enterprises in Poland in 2020 results from the impact of the COVID-19 infectious disease pandemic.

In the period from March 11, 2020 to the end of May 2020, remote work was obligatory throughout Poland, including in private enterprises. This, in turn, has led to an increase in the need for software that allows realtime online communication and information transfer. Most of the employees were not in their workplaces, and performed the duties imposed by the employer in their place of residence. These types of changes required enterprises to purchase specialized software, and to change the management of their entities through its im- 
plementation, continuous analysis and evaluation of work on it in a dynamic perspective. Taking into account these circumstances, the surveyed private entrepreneurs perceived technical problems resulting from remote work and the risks associated with attempts to obtain ICT data by unauthorized persons among the threats. Such actions can be defined as threats to information security, which entrepreneurs counteract on their own by using internal solutions, the last resort in this respect is the use of the help of law enforcement agencies.

Government administration bodies have prepared tools to counteract the COVID-19 pandemic in the form of, for example, "Anti-crisis shield 2.0" and "Financial Shield of the Polish Development Fund" (https://www. garrigues.com/pl/pl-PL/news/tarcza- anti-crisis-20-solutions-in-the-field-labor-law; as of November 4, 2021), which solutions were positively assessed by the surveyed private entrepreneurs. The employers obtained funding from the government administration. The co-financing concerned $75 \%$ of non-returnable subsidies, which were aggregated according to three groups in the form (https://www.garrigues.com/pl/pl-PL/news/tarcza-finansowa-polskiego-fundusz-rozojny):

- Micro-enterprises (from 1 to 9 employees) - subsidies with a maximum amount of PLN 324,000 for a period of 3 years. In the group under consideration, the annual turnover or balance sheet total may not exceed EUR $2,000,000$.

- Small and medium-sized enterprises (from 10 to 250 employees) - maximum co-financing up to PLN 3 $5,000,000$ for a period of 3 years. In the group under consideration, the annual turnover may not exceed EUR 50,000,000 or the balance sheet total of EUR 43,000,000.

- Large enterprises (over 250 employees) - financing provided on a case-by-case basis. The annual turnover in the third group may not exceed EUR 50,000,000, or the balance sheet total of EUR 43,000,000. The funds obtained by entrepreneurs as part of the subsidy could cover the costs of operations, loan repayment or settlements with related entities.

The condition for granting the subsidy was to demonstrate a decrease in economic turnover by at least in any month after February 1, 2020 compared to the previous month, or the same month in the previous year. Employment protection for employees was introduced by employers until the subsidy is fully collected, as well as ZUS contribution payers who, as of February 29, 2020, reported 10 to 49 insured employees to social insurance, were dismissed up to $50 \%$ of the total amount of unpaid contributions.

\section{Multidimensional comparative analysis of the market in Poland - from the perspective of private enterprises}

One of the analyzed groups of variables is the number of notes and coins in circulation, which is the number of general circulation notes and coins in circulation at the end of a given period, less the number (or value) of notes and coins: in the NBP vaults and vaults, deposited by the NBP to deposit in vaults of other banks withdrawn from circulation by NBP due to the degree of their wear (Kołodziejczyk, 2015). The circulation of money concerned nonfinancial enterprises in Poland. Narodowy Bank Polski (NBP) defines non-financial enterprises as entities whose main activity is the production and trade in goods or provision of non-financial services, in particular: state-owned enterprises and companies operating on the basis of the Act of 25 September 1981 on state-owned enterprises (Journal of Laws of 2021, item 1317 as amended) and state-owned companies (NBP, 2020). They are in this group:

- municipal enterprises,

- research and development units, with the exception of units included in the general government sector mentioned in the description of this sector,

- Poczta Polska S.A.,

- agencies that have not been listed as entities included in the sub-sector of central government institutions and meet the above-described conditions for state-owned companies (https://www.nbp.pl/statystyka/ sprawozdawczosc/form/ In Edukacja-wypel single- reporting-statystyka-stat-2020.pdf).

In conclusion, non-financial enterprises are interpreted as functioning profit-oriented enterprises that sell everything except money (Market Entities, 2021). 
The research began with the preparation of a bar chart of data on money in circulation in enterprises in Poland from January 2018 to August 2021, in PLN million.

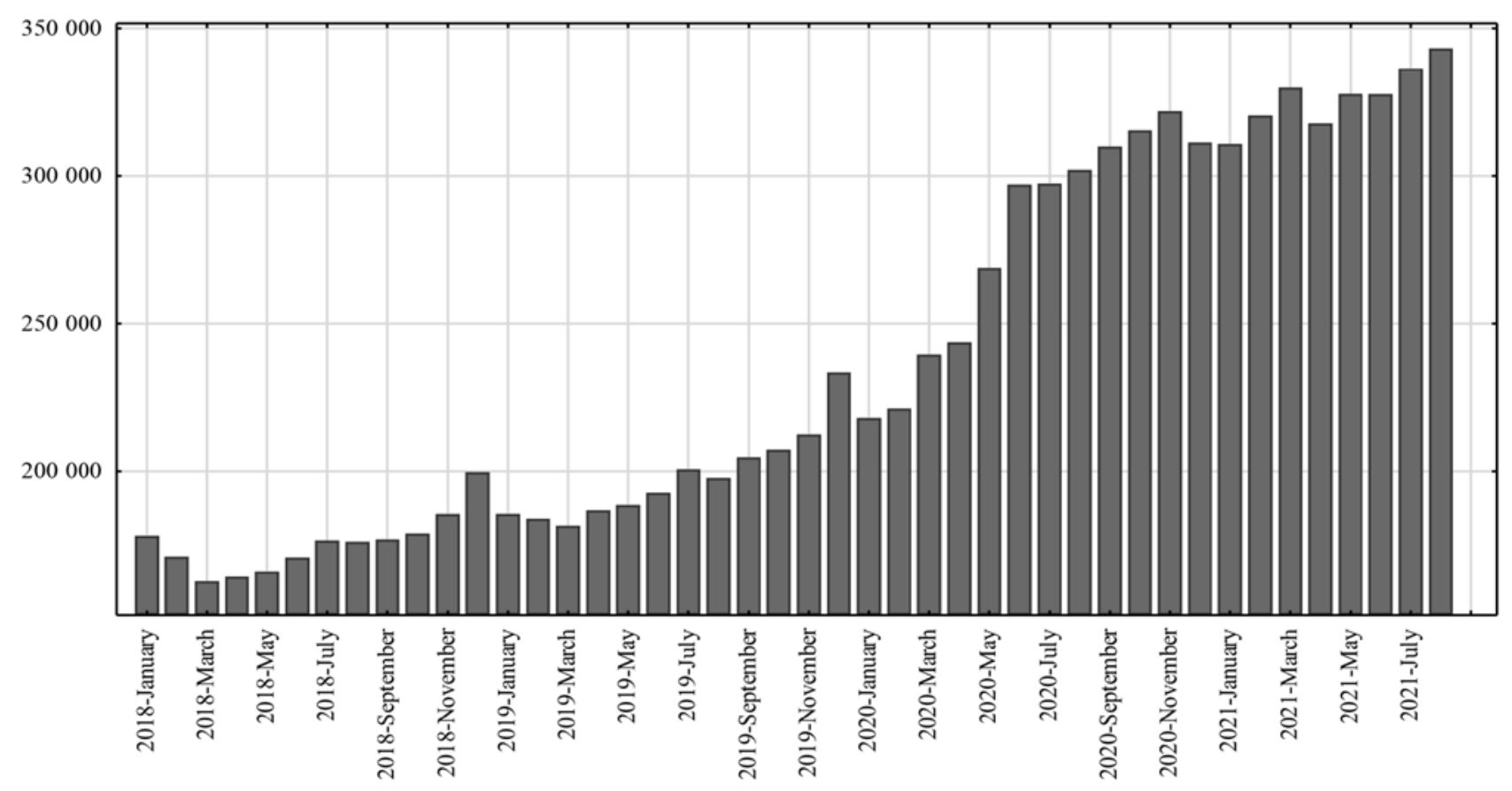

Figure 2. Bar chart of the number of notes and coins in circulation in enterprises in Poland from January 2018 to August 2021 in PLN million.

Source: https://www.nbp.pl/ (Date of access: October 14, 2021).

The observation of the data in Figure 2 allows us to conclude that from May 2020 there is a strong upward trend in the number of notes and coin in circulation in enterprises in Poland compared to the data from January 2018 to April 2020. This was dictated by the financial crisis caused by the COVID-19 pandemic. The arithmetic average of the number of notes and coin in circulation in enterprises in Poland in 2018 amounted to PLN 175,545.5 million. In 2019, it increased to PLN 197,902.1 million, and in 2020 to PLN 278,912.7 million. By August 2021, it had reached the level of PLN 326,819.2 million. This clearly indicates a strong upward trend. It should be emphasized that with the increase in the amount of money in circulation in enterprises in Poland from May 2021, an increase in the standard deviation was observed. In 2020, it amounted to PLN 38,500.97 million, and in 2021 it fell to PLN 10,368.64 million. It should be emphasized that from March 2020 (the emergence of the COVID-19 pandemic), there was an increase in the volume of money circulation in enterprises in Poland from PLN 239,619.986 million to PLN 343,288.39 million in August 2021.

For illustrative purposes, in order to examine the dynamics of the increase in the number of notes and coins in circulation in enterprises in Poland on a monthly basis from February 2018 to August 2021, Fig. Poland in January 2018. 


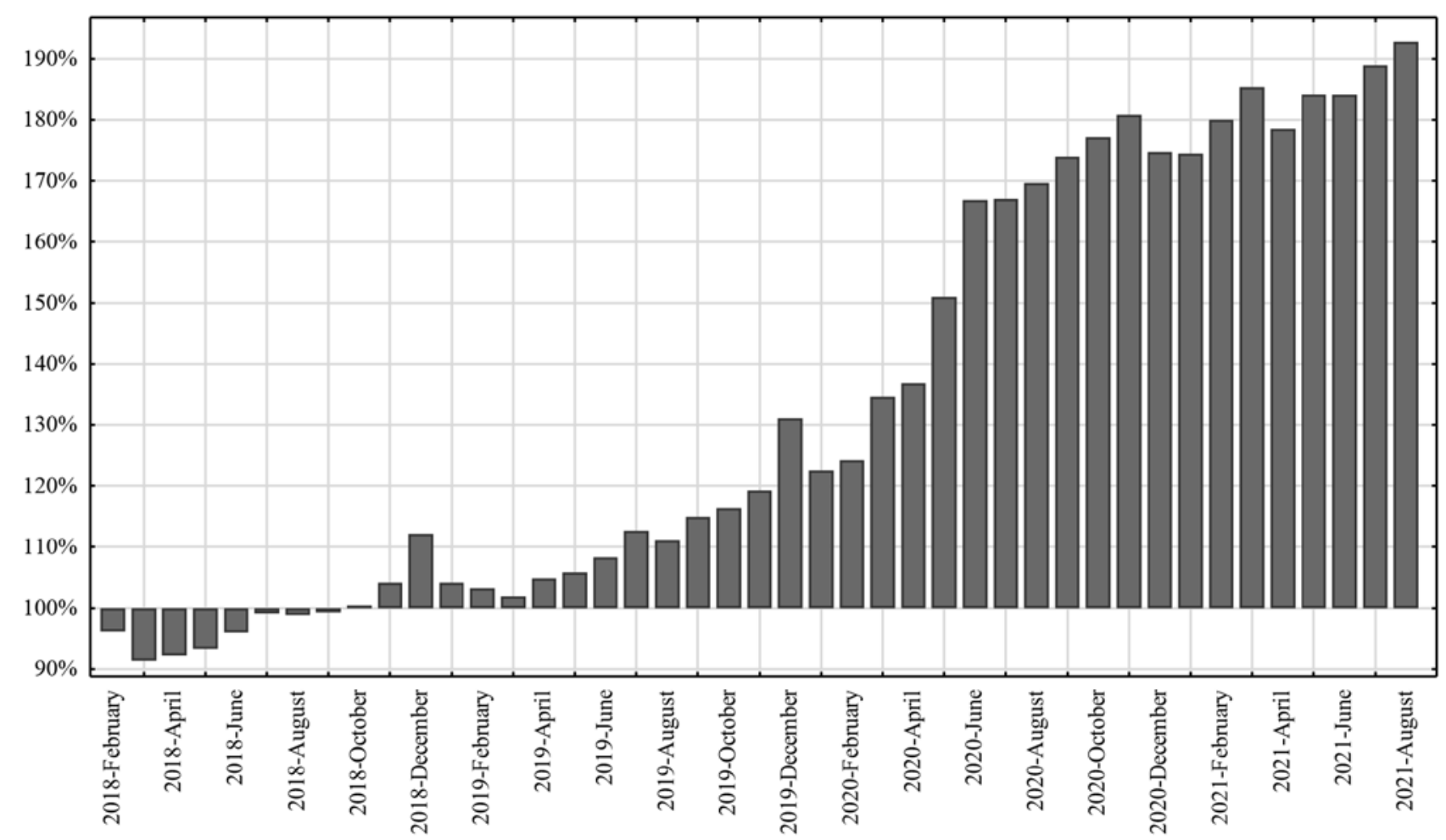

Figure 3. Bar chart of dynamics indicators with a fixed base (constant: January 2018) of money in circulation in enterprises in Poland from February 2018 to August 2021.

Source: https://www.nbp.pl/

The data in Figure 3 shows that from February to September 2018, there was a visible decrease in the dynamics of the dynamics based on the number of notes in circulation in enterprises in Poland. Strong growth was observed in December 2018. From April 2019 (104.85\%), an increase in the dynamics of the number of notes and coins in circulation in enterprises in Poland can be observed - until April 2020 (136.59\%). On the other hand, from May 2020 (151.03\%), a very strong increase is visible, which lasts until August 2021 (192.79\%). The increase from January 2018 to August 2021 was by 92.79 pp, i.e. by PLN 165221.224 million. The COVID-19 pandemic, announced from March 11, 2020, contributed to an increase in the amount of money in circulation in enterprises in Poland. It has also led to a sharp increase in unemployment worldwide, including in the United States. From February to April 2020, the unemployment rate increased by 11.2 pp, to $14.7 \%$. In Poland, measures in the form of anti-crisis and financial shields were implemented, which stopped the strong increase in unemployment. This was due to the implemented contracts between the government and entrepreneurs to support them financially in return for not firing employees for the period of receiving subsidies. The surveyed entrepreneurs positively assessed this solution. The values of unemployment rates and the number of the unemployed are presented in Figure 4. 


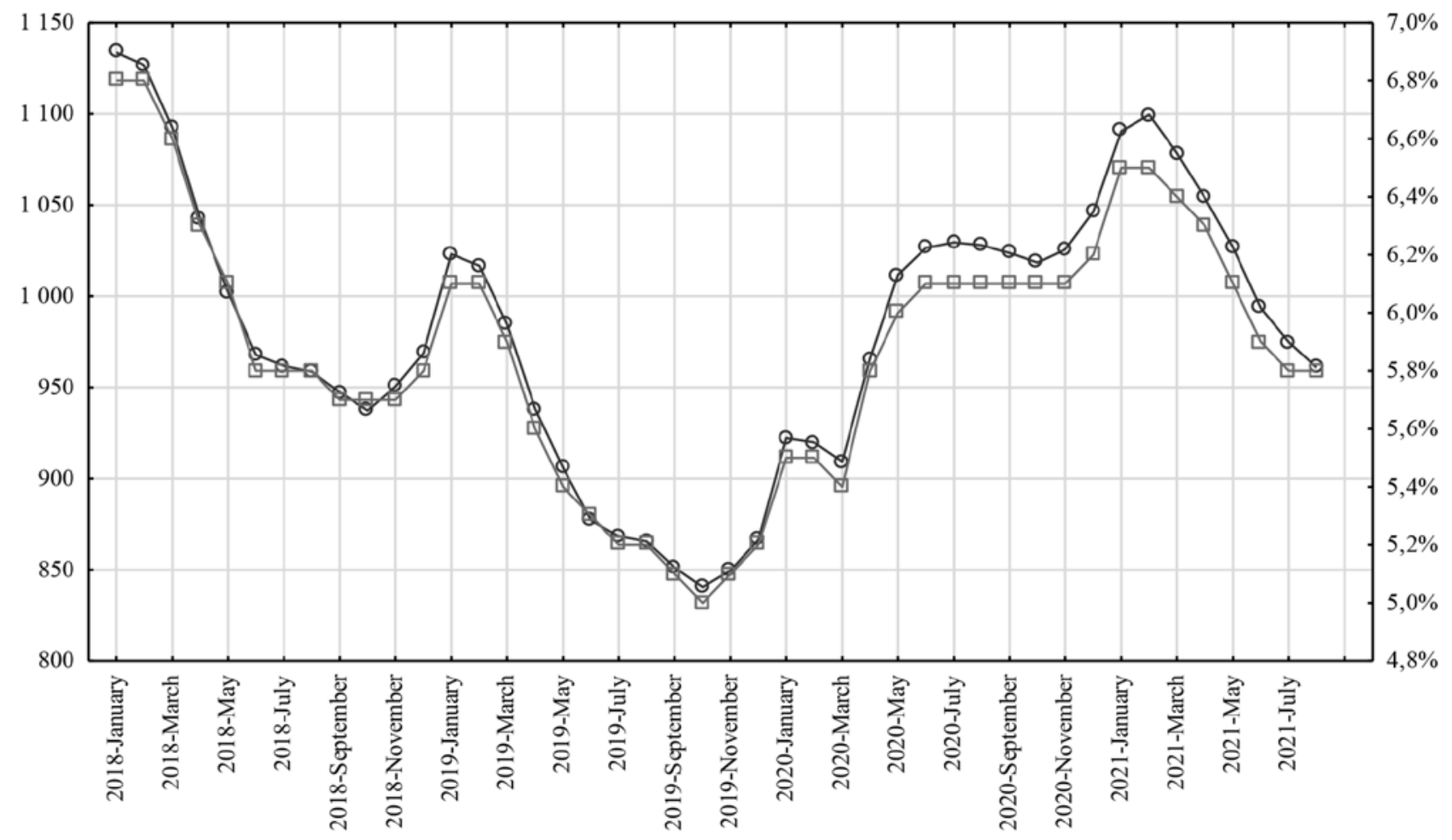

๑- Unemployment (L)

$\because$ Unemployment index (R)

Figure 4. Line chart of unemployment measures (right axis $\mathrm{Y}$ in\%) and the unemployed (left axis Y in thousands) in Poland from January 2018 to August 2021

\section{Source: https://www.stat.gov.pl/}

Figure 4 shows that from January (6.8\%) to October $2018(5.7 \%)$ a downward trend in the inflation rate and the number of unemployed people in Poland was visible. An upward trend was observed from October 2018 (5.7\%) to February 2019 (6.1\%). The largest drops in unemployment rates and the number of unemployed in Poland in the analyzed research period were from February 2019 (6.1\%) to October $2019(5 \%)$. Then there was a strong upward trend in unemployment rates to around $6.4 \%$ by March 2021.

Figure 3 shows a strong increase, especially from March to June 2020 (from 5.4\% to 6.1\%), i.e. during the period of a strong impact of the COVID-19 pandemic. Important and good news for the Polish economy is the decline in unemployment rates in Poland from February (6.5\%) to August 2021 (5.8\%). The situation could have been caused by the return of Polish citizens from work abroad and new needs arising on the markets resulting from the impact of the COVID-19 pandemic. The increase in unemployment during the COVID-19 pandemic in Poland and in the world was also indirectly influenced by the situation related to the stoppage of the air transport sector. This, in turn, led to a decline in world prices for one barrel of crude oil. Information on the price of a barrel of crude oil is outlined in Figure 5. 


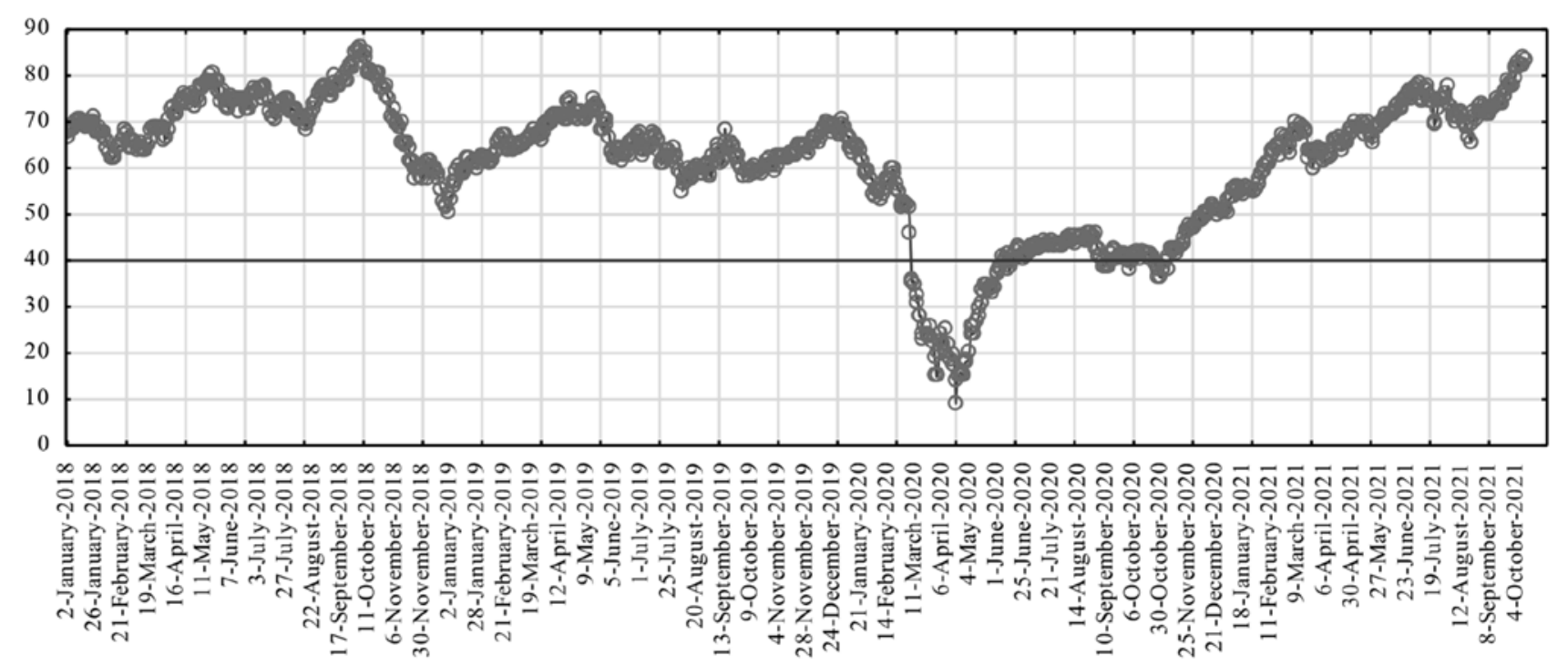

Figure 5. Daily line chart of a barrel of crude oil from January 2, 2018 to October 12, 2021 in dollars.

Source: https://www.eia.gov/dnav/pet/hist/RBRTED.htm

The COVID-19 pandemic has caused a prolonged fall in prices per barrel of crude oil. It was particularly noticeable in the time frame from March 6, 2020 (\$45.6 / barrel) to April 21, 2020, where the price per barrel of crude oil fell to $\$ 9.12$. It then saw an increase to $\$ 40$ a barrel on June 5, 2020. By the end of November 2020, the price was around $\$ 40$. It should be emphasized that the countries that extract crude oil and receive national income from it, suffered losses during this period. Russia is one of these countries. From October 2020 (\$47.3 / barrel), a strong upward trend in oil prices per barrel is visible. On October 12, 2021, the price of a barrel of crude oil rose to $\$ 83.53$. The increases in crude oil prices translated into dynamic increases in inflation in Poland - Figure 6.

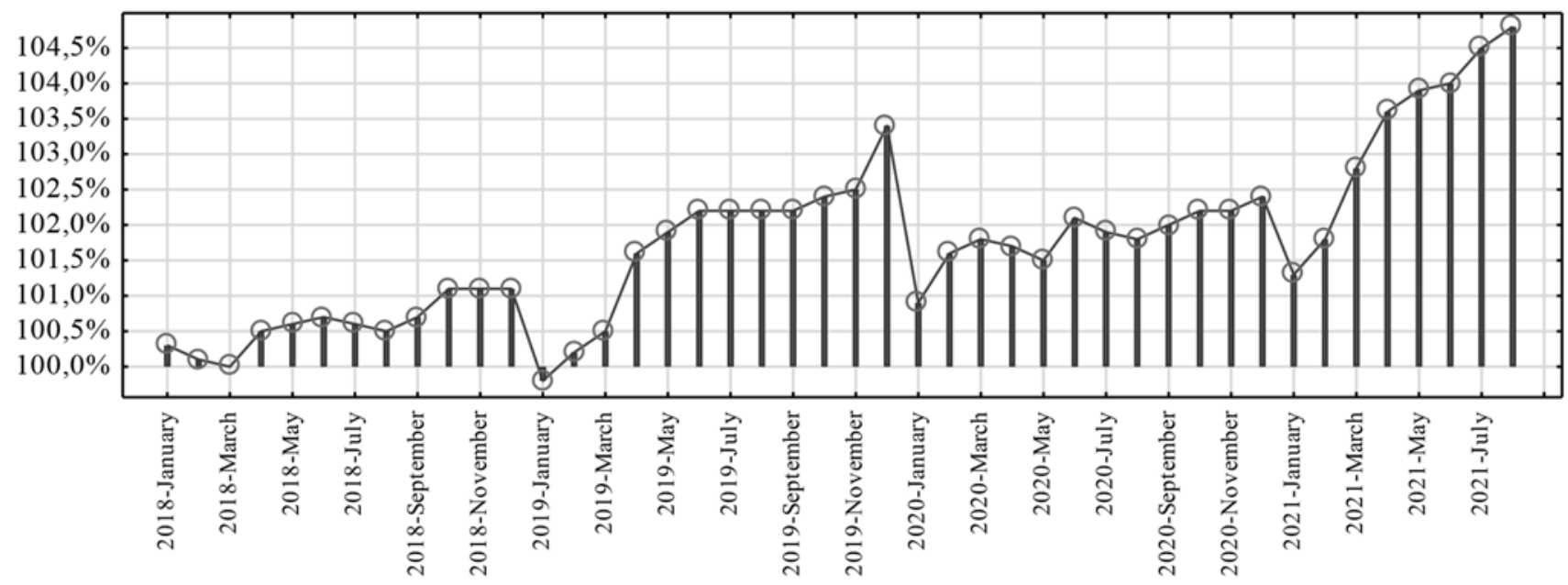

Figure 6. Bar chart of inflation measures in Poland from January 2018 to August 2021 in\%

Source: https://stat.gov.pl/ (Date of access: October 14, 2021)

The observation of Figure 6 allows us to conclude that the inflation rate in Poland at the beginning of the COVID-19 pandemic, due to, inter alia, low oil prices, showed a constant level oscillating between March (101.8\%) and December 2020 (102.4\%) around 101.96\%. However, since January 2021, i.e. the global increase in oil prices, inflation in Poland has also increased strongly. From January 2021 (101.3\%) to August 2021 (104.8\%), there was an increase in inflation by 3.5 percentage points. The situation related to the increase in inflation and 
world oil prices may lead to a large increase in unemployment in Poland in the future. At this stage, it is important to provide entrepreneurs with the appropriate level of financial resources to survive the crisis.

\section{Conclusions}

The use of many dependent variables in the study of different and uniform units of time allows for assessments related to volatility in the markets. This type of solution was used in the study. During the COVID-19 pandemic in 2020, there was an increase in enterprises in Poland by 159,000. In 2020, there were 329,000 newly established enterprises, and 170,000 were declared bankrupt. The COVID-19 pandemic led to an increase in the amount of money in circulation in private enterprises. From March 2020 (the appearance of the pandemic), there was an increase in the volume of money circulation in enterprises in Poland from PLN 239619.986 million to PLN 343288.39 million in August 2021. The actions of government administration bodies in the form of the implementation of the Anti-Crisis Shield 2.0 and the "Financial Shield of the Polish Development Fund" were aimed at securing the economy in terms of stopping the unemployment growth and thus maintaining an appropriate level of the inflation stop in dynamic terms. In the initial phase of the COVID-19 pandemic from March to June 2020, an increase in unemployment in Poland was observed from 5.4\% to 6.1\%. Important and good news for the Polish economy is the decline in unemployment rates in Poland from February (6.5\%) to $\mathrm{Au}-$ gust 2021 (5.8\%). This could have been caused by the return of Polish citizens from work abroad, and mainly by the new needs for services that reopened after the worst pandemic period. The COVID-19 pandemic caused a long-lasting fall in the price of one barrel of crude oil. From October 2020 ( $\$ 47.3 /$ barrel), a strong upward trend in oil prices is visible. On October 12,2021 , the price of a barrel of crude oil rose to $\$ 83.53$. The inflation rate in Poland at the beginning of the COVID-19 pandemic, due to, inter alia, low oil prices, remained at a constant level oscillating in the period from March (101.8\%) to December 2020 (102.4\%) around 101.96\%. Since January 2021, i.e. the global increase in oil prices, inflation in Poland has increased significantly. In January 2021 it was $101.3 \%$ and by August 2021 it increased by $3.5 \mathrm{pp}$. The situation related to the increase in inflation and world oil prices may lead to a large increase in unemployment in Poland in the future. Counteracting the COVID-19 pandemic requires the cooperation of various world economies in terms of the development and implementation of long-term international agreements, as well as the continuous analysis and assessment of the history of changes in the markets in terms of strengthening Poland's financial security. In this respect, further work and development of statistical inference methods are necessary.

\section{References:}

Begg, D., Vernasca, G., Fischer, S., Dornbusch, R, Makroekonomia (Macroeconomics), Warszawa 2014.

Jurgilewicz M., Rola podmiotów uprawnionych do użycia lub wykorzystania środków przymusu bezpośredniego i broni palnej w ochronie bezpieczeństwa i porzadku publicznego (The role of entities authorized to use or use means of direct coercion and firearms in the protection of public safety and order), Siedlce 2017.

Kingsley, K., Kouam, H., January 2020, COVID-19 and oil prices, SSRN Electronic Journal.

Kołodziejczyk, J., Narodowy Bank Polski. Obieg pieniadza w Polsce, (National Bank of Poland. The circulation of money in Poland), https://konferencje.alebank.pl/wp-content/uploads/2015/09/prezentacja.joanna.kolodziej.pdf

Kurek, S., 2000, Bezpieczeństwo ekonomiczne państwa [w:] Ekonomika bezpieczeństwa państwa średniej wielkości. Teoria i praktyka, (Economic security of the state, [in:] Economics of medium-sized state security. Theory and practice) S. Kurini i M. Krča (red.) (Warszawa-Brno).

Łuniewska, M., Tarczyński, W., 2006, Metody wielowymiarowej analizy porównawczej na rynku kapitałowym, (Methods of multidimensional comparative analysis on the capital market), Warszawa.

Matuka, A., September 2020, COVID-19 Outbreak and US Economic Policy Uncertainty: An ARDL Approach, SSRN Electronic Journal.

Mitkow, Sz., Kozicki, B., 2021, Multidimensional comparative analysis and forecasting of unemployment in the USA for 2021 in the aspect of economic security, International Business, Information Management Conference, 37th IBIMA (Cordoba, Spain).

Narodowy Bank Polski, https://www.nbp.pl/statystyka/sprawozdawczosc/form/Instrukcja-wypelniania-formularzy-sprawozdawczych- 
JOURNAL OF SECURITY AND SUSTAINABILITY ISSUES

ISSN 2029-7017 print/ISSN 2029-7025 online

statystyka-stanow-2020.pdf

Nurzyńska, A., 2016, Bezpieczeństwo usług w międzynarodowym transporcie lotniczym przewozów pasażerskich, (Security of services in international passenger air transport), Katowice.

Owsiak, S., 2015, Finanse, (Finance), Warszawa.

Satomi E., et al., April 2020, Alocação justa de recuros de saúde escassos diante da pandemia de COVID-19. Considerações éticas, Einstein (São Paulo 18(2):1-5).

Zhu, N., Zhang, D., Wang, W., et al. 24 January 2020, A Novel Coronavirus from Patients with Pneumonia in China, 2019, New England Journal of Medicine.

Zimon G., Jurgilewicz M., Kmiotek K., Financial Security Management in Central Units of Purchasing Groups, WSEAS Transactions on Business and Economics, Volume 17, 2020, s. 910-920.

Internet resource: https://www.gov.pl/web/tarczaantykryzysowa

Internet resource: https://www.parp.gov.pl/storage/publications/pdf/PARP-26_Raport-2021-07-22_WCAG_210726.pdf

Internet resource: https://www.garrigues.com/pl/pl-PL/news/tarcza-antykryzysowa-20-rozwiazania-w-dziedzinie-prawa-pracy

Internet resource: https:/www.garrigues.com/pl/pl-PL/news/tarcza-finansowa-polskiego-funduszu-rozwoju

Juliusz PIWOWARSKI is the Professor at the University of Public Safety and Individual APEIRON in Krakow, PL. Research interests: international security.

ORCID ID: 0000-0002-9196-1194

Bartosz KOZICKI is an assistant professor at the Military University of Technology, PL. Research interests: national security, internal security.

ORCID ID: 0000-0001-6089-952x

Marcin JURGILEWICZ is the Professor at Rzeszów University of Technology, PL. Research interests: internal security, law, mediation.

ORCID ID: $0000-0003-2243-2165$

Norbert MALEC is the Professor at University of Natural Sciences and Humanities in Siedlce, PL. Research interests: international security.

ORCID ID: 0000-0003-0119-2705 